\title{
The Presumption Against \\ INTERFERENCE WITH VESTED RIGHTS: \\ Creating Structure out OF THE CONFUSion
}

\author{
MiCHAEL CUSTER ${ }^{*}$
}

\begin{abstract}
Canadian courts interpret statutes flexibly, as they remain unbridled by strict interpretive rules or principles. Consequently, ambiguity in statutory interpretation has emerged, particularly regarding the temporal application of statutory amendments. In this article, the author suggests that clearer rules should be established to remedy such uncertainty, focusing predominantly on clarifying the presumption against interference with vested rights. The article first proposes a step-by-step approach to the vested rights analysis, explaining how it operates and interacts with other temporal application presumptions. Next, the article traces the history and jurisprudence of the presumption against interference with vested rights, and attempts to resolve outstanding issues relating to the presumption. Finally, it applies this background to the proposed step-by-step approach, ultimately synthesizing the law and theory underpinning the discussed presumptions.
\end{abstract}

\section{TABLE OF CONTENTS}

I. INTRODUCTION . . . . . . . . . . . . . . . . . . . . . . . . . . . . . . . 1090

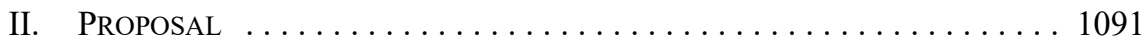

III. A TeMPoral APPLicAtion Primer . . . . . . . . . . . . . . . . . . . 1092

IV. Separating Vested Rights From Retrospectivity . . . . . . . . . . . 1095

V. THE BROAD ORIGINS AND NARROWING

DEVELOPMENT OF THE PRESUMPTION . . . . . . . . . . . . . . 1098

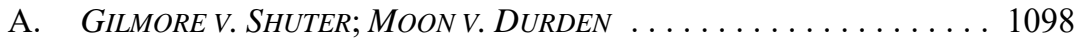

B. ABBOTT V. MINISTER FOR LANDS . . . . . . . . . . . . . . 1099

C. WEST V. GWYNNE ......................... 1100

VI. The Presumption's Twentieth Century

TREATMENT In CANADA $\ldots \ldots \ldots \ldots \ldots \ldots \ldots \ldots \ldots \ldots \ldots \ldots \ldots \ldots \ldots \ldots$

A. ACME VILLAGE SCHOOL DISTRICT NO. 2296

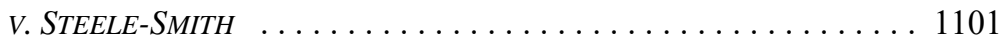

B. GuSTAVSON DRILLING (1964) LTD. V. MNR . . . . . . . . . . . 1102

VII. THE MOdERn REFINEMENT OF THE PRESUMPTION ............... 1104

A. SCOTT V. COLLEGE OF PHYSICIANS

AND SURGEONS OF SASKATCHEWAN . . . . . . . . . . . . . . . . . . . 1104

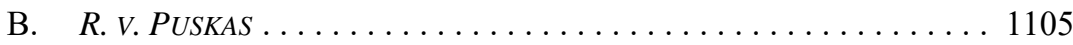

C. DikRANIAN V. QUEBEC (ATTORNEY GENERAL) . . . . . . . . . . 1105

VIII. Defining THE SCOPE Of A Vested Right $\ldots \ldots \ldots \ldots \ldots \ldots \ldots \ldots$

IX. Defining the StRength OF THE

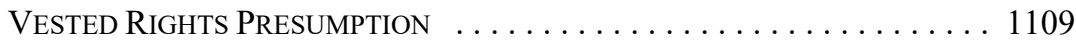

JD Candidate, 2018, University of Alberta Faculty of Law. I would primarily like to thank Dr. Cameron Hutchison at the Faculty of Law, University of Alberta, who introduced me to this topic as my Statutory Interpretation professor, took me on as his student researcher, and provided me with encouragement and helpful comments throughout the writing process of this article. Any errors, however, are mine. I am also indebted to the two anonymous reviewers who highlighted the points of the article which required more attention; the final product is much better off because of it. Finally, an honourable mention goes out to those of my friends and family who patiently listened to me ramble repeatedly on this topic of law: Dave Custer, Edith Bérard-Custer, Marc Custer, Jordyn Dryden, Zubair Hussain, and Robert Marquette. 


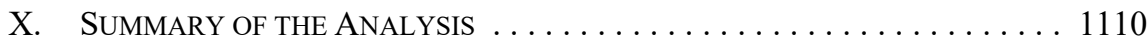

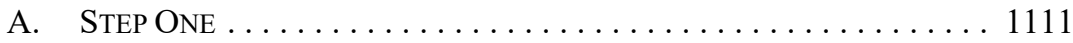

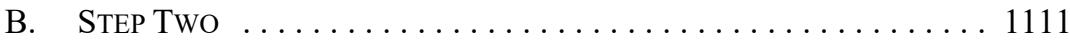

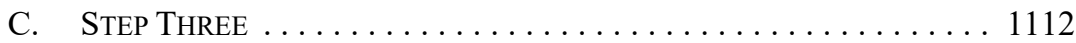

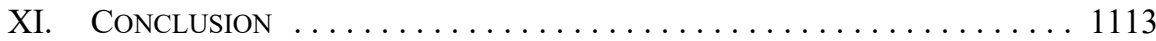

\section{INTRODUCTION}

Statutory interpretation is, by its nature, a subject that tends to evade strict rules and frameworks; it must often be flexible and adaptive if it is to be an effective tool. However, this lack of clarity can prove confusing to judges and lawyers when they are confronted with issues of temporal application in determining the reach of statutory amendments. Authorities are split as to the meaning, scope, and strength of various presumptions of temporal application, and this uncertainty is often on full display in the variety of judicial opinions that have emerged on the topic. This article aims to provide a synthesis of the jurisprudence and theory behind one presumption of statutory interpretation in particular: the presumption against interference with vested rights.

The presumption against interference with vested rights rests on a very simple rationale: it is often unfair for new legislation to intrude upon rights that individuals have validly and legally acquired in the past. ${ }^{1}$ The presumption can apply, for example, where new legislation alters the effects of an ongoing contract, where it would take away a right of action after a proceeding has commenced, or where a business venture, which was previously legal, is deemed illegal. What counts as a vested right, how the corresponding presumption operates, and what considerations go into rebutting it, are points that have all been constantly in flux since the concept's inception.

In the first part of this article, I propose that a clearer framework is required when approaching a vested rights analysis. Judges and lawyers too often venture into the topic armed only with vague and conflicting precedent at their disposal. By suggesting a step-bystep analysis, my hope is that a vested rights analysis becomes less of an ad hoc process, and more of a structured one. In the sections following that proposal, I will explain how the presumption against interference with vested rights operates alongside the other presumptions of temporal application; while it would be far simpler to study the vested rights presumption in isolation from the rest of the temporal application presumptions, this would leave us with a very incomplete picture of its role in the broader analysis. Much of this article, therefore, will also touch upon the presumption against retrospectivity, a presumption that is often invoked alongside the vested rights presumption. This will provide a more complete summary of the law of temporal application as it stands today.

Following this, the origins of the presumption against interference with vested rights will be explored, detailing how it evolved from a rather strong, broad presumption in the early 1600 s to a much more heavily qualified and caveated one as time went on. I will also examine more closely how several recent cases have changed the way that the presumption is applied in the courts, and how these decisions can be reconciled with each other. This 
article will not attempt to catalogue each case that deals with the presumption, but will rather only highlight some of the most important cases in order to simplify the law in this area.

Finally, the last several sections of this article will attempt to resolve some outstanding issues related to the vested rights presumption, such as the strength and scope of the presumption, and summarize the proposed framework with reference to the listed cases as justification.

\section{Proposal}

Over time, judges have approached the presumption against interference with vested rights in different ways. Pierre-André Côté has noted that in some cases, "courts will often weigh the social and individual consequences, usually without saying so" when choosing whether or not to recognize the existence of a vested right. ${ }^{2}$ He goes on to note that the "perception of injustice" is a determinative factor for courts, and that " $[\mathrm{t}]$ he greater the prejudice suffered by the individual, the greater are the chances that vested rights will be recognized." 3 This article proposes that the trend that Côté has recognized requires some modification in order for courts to approach the presumption against interference with vested rights in a more coherent way.

The analysis should instead be broken down into several distinct parts:

(1) Does the new legislation affect a substantive right, or a mere matter of procedure?

(2) If a substantive right is affected, has that right been "acquired" by or "vested" in the individual?

(a) Is the claimant in a distinct legal position?

(b) Has the claimant sufficiently exercised the right in question?

(3) If it is a vested right, is there sufficient evidence of legislative intent to rebut the presumption against interference with vested rights?

At the first stage of the analysis, it must be ensured that the right that one seeks to shelter under the presumption is a substantive right, and not a mere matter of procedure. ${ }^{4} R . v$. Dineley is the authoritative case in this regard. ${ }^{5}$ Any vested right must be substantive, as

Pierre-André Côté, The Interpretation of Legislation in Canada, 4th ed (Toronto: Thomson Reuters Canada, 2011) at 168.

Ibid at 169.

Ruth Sullivan, Sullivan on the Construction of Statutes, 6th ed (Markham, Ont: LexisNexis Canada, 2014) [Sullivan, Construction]. Sullivan states that "[t]he court must decide whether the particular interest or expectation for which protection is sought is sufficiently important to be recognized as a right and sufficiently defined and in the control of the claimant to be recognized as vested or accrued" (ibid at para 25.140). While the second part of this framework is sound, the first is far too ambiguous because the concept of what is "important" enough to be a right will vary substantially from judge to judge. At the early stage, I propose that it is sufficient to simply separate the substantive rights from pure procedures, and then to move on to determine whether or not the substantive rights are vested. The importance of the right in question (namely, the prejudicial effect its deprivation would have on the claimant) is a factor better dealt with under the third stage of the analysis.

2012 SCC 58, [2012] 3 SCR 272 [Dineley]. 
nobody can have a vested right to a simple procedure. ${ }^{6}$ It should be noted that questions of procedural change usually arise in the context of either judicial procedure or administrative law. ${ }^{7}$ Next, the analysis turns to whether the right is "acquired," making it a vested right rather than simply a substantive but non-vested right. This portion of the test should be conducted with no resort to contextual factors, such as the remedial nature of the legislation or the unfair effects on the claimant; it should examine only the right itself, and what steps were taken to claim it. It is only in the final portion of the analysis, where we examine whether the presumption can be rebutted, that courts should take into account the "[weighing of] social and individual consequences," and the prejudices suffered by the party. ${ }^{8}$

There are two main advantages to this method of structuring the analysis. First, the process of recognizing the vested right itself is insulated from the contextual considerations, which vary from case to case. If prejudice and social factors are taken into account at the stage of the analysis where the vested right itself is recognized, then what counts as a vested right in one situation may very well not count in another depending on the relative levels of unfairness involved in both instances. Such an outcome is possible if, as Côté has noted, the very existence of a claimant's vested rights depends on the amount of prejudice at play in their situation. ${ }^{9}$ This, I would argue, is a poor way to build consistent precedent, and will likely lead to conflicting decisions down the road.

The second advantage to this framework is that over time, it will help clarify the strength that the presumption against interference with vested rights attracts in an analysis. When the contextual factors that are considered in the final stage of the analysis also influence the likelihood that a vested right will be recognized in the first place, the result is a very skewed image of how strong the presumption really is; such a distortion makes it nearly impossible to discern the strength of the presumption over time. Keeping the two stages separate allows for a more accurate image of the presumption to emerge, one that clarifies the proper weight to be given to the presumption.

\section{A Temporal Application Primer}

The presumption against interference with vested rights is one of several "presumptions of legislative intent" that could be in play in situations where the temporal application of new legislation is at issue. These presumptions of legislative intent, functionally speaking, are tools used to deal with situations where it appears that the legislature did not contemplate the 
issue before the court. ${ }^{10}$ In the Canadian context, courts have recognized four primary rules of construction:

(1) There is a strong presumption against the retroactive application of legislation;

(2) there is a presumption against the retrospective application of legislation;

(3) there is a presumption against interference with vested rights; and

(4) there is a presumption that procedural legislation, as opposed to substantive legislation, applies "immediately to pending or ongoing proceedings." "11

The first hurdle to overcome in understanding the differences between these presumptions is to understand the distinction between the terms "retroactive" and "retrospective." This is perhaps the most frustrating aspect of the law of temporal application. Canadian jurisprudence differs from the law in the United Kingdom and the United States in that it now treats the two terms as distinct, rather than interchangeable. ${ }^{12}$ This separation of the terms made its introduction into Canadian law with the publication of Elmer Driedger's oft-quoted article "Statutes: Retroactive Retrospective Reflections," where he stated that:

\begin{abstract}
A retroactive statute is one that operates as of a time prior to its enactment. A retrospective statute is one that operates for the future only. It is prospective, but it imposes new results in respect of a past event. A retroactive statute operates backwards. A retrospective statute operates forwards, but it looks backwards in that it attaches new consequences for the future to an event that took place before the statute was enacted. A retroactive statute changes the law from what it was; a retrospective statute changes the law from what it otherwise would be with respect to a prior event. ${ }^{13}$
\end{abstract}

Imagine, for example, the following scenario. Party $\mathrm{A}$ is in the market for a car and decides to go to Party B for a loan to finance the purchase of the car. Party B agrees, and grants Party A the loan at a 10 percent interest rate. They concluded this agreement in 2017. Then, one year later, the government passes legislation designed to protect unwary borrowers from loan sharks, and caps all car loans at a maximum 5 percent interest rate. The question

10 Ruth Sullivan, "The Plain Meaning Rule and Other Ways to Cheat at Statutory Interpretation" in Ejan Mackaay, ed, Certainty and the Law (Montreal: Thémis, 2000) 151 [Sullivan, "Ways to Cheat"]. Sullivan highlights the ways in which judges "cheat" at statutory interpretation, noting that these presumptions are legal fictions, whereby the courts pretend that it is Parliament's intention that they are implementing rather than simply their own at 186 :

When it appears that the legislature never considered the problem facing the court, when there is no relevant evidence of legislative intent, the court has no choice but to make something up.

However, any embarrassment that might flow from such unavoidable bouts of judicial lawmaking is avoided by presuming that the part made up by judges is in fact what the legislature intended all along.

11 Sullivan, Construction, supra note 4 at 761, cited in Almalki, supra note 6 at para 34. Note that I have intentionally omitted Sullivan's proposal that the presumptions against retrospectivity and interference with vested rights be classified as "variable" presumptions; my reasons for doing so are outlined later in this article.

12 See Wilson $v$ Secretary of State for Trade and Industry, [2003] UKHL 40, [2004] 1 AC 816 at paras 186-87 (for the United Kingdom's treatment of the terms); Norman J Singer \& JD Shambie Singer, Statutes and Statutory Construction, 7th ed, vol 1A (Eagan, Minn: Thomson Reuters, 2009) at 382-85 (for the United States' treatment of the terms).

13 Elmer A Driedger, "Statutes: Retroactive Retrospective Reflections" (1978) 56:2 Can Bar Rev 264 at 268-69 [emphasis in original ] [Driedger, "Reflections"]. 
then becomes: how does this new 2018 legislation affect the 2017 agreement between Party A and Party B?

If the legislation has retroactive effect, then the law would change the past legal effects of the past event (namely, the formation of the contract). The result would effectively be a declaration that the maximum interest rate was always 5 percent, and Party B would likely owe Party A money for any amount that was paid over and above the 5 percent cap in the past. It is not difficult to see why there is a strong presumption against this sort of effect. As Sullivan points out, "[i]t is obvious that reaching into the past and declaring the law to be different from what it was is a serious violation of rule of law," given that those who were acting in accordance with the law at the time are now penalized for it. ${ }^{14}$ Nevertheless, if the legislature explicitly makes it clear that the law is to have retroactive effect, or there is a necessary implication that this is the case, then the presumption can be rebutted. ${ }^{15}$ An example of such an instance would be where the legislature states that the legislation is deemed to have come into force on a day prior to its commencement, meaning that it governs legal effects that occurred before the legislation ever came into effect. ${ }^{16}$

On the other hand, if the legislation has retrospective effect, then the legislation would change only the future legal effects of the past event. In this case, the amount of interest that had been paid from the formation of the contract in 2017 to the coming into effect of the legislation in 2018 would be untouched, but from 2018 onwards the interest rate would be capped at 5 percent. Sullivan refers to this as a "variable" presumption, with its strength "depending on factors such as the nature of the disadvantage imposed by the legislation and the degree to which imposing it would be arbitrary or unfair." ${ }^{17}$ While it would still be arbitrary to limit Party B's profits in the future from a contract that was perfectly valid when it was signed, the fact that there is no confiscation of past benefits makes this a less unfair outcome than the retroactive effect would be, and thus the presumption against retrospective application is more easily rebutted than the presumption against retroactive application. This effect can also be contrasted against a purely prospective application, which impacts only the future legal effects of future situations: contracts signed in the past would be unaffected, and in our scenario the 10 percent interest rate could continue onwards to the end of the contract unimpeded.

The presumption against interference with vested rights applies whether the legislation in question is retrospective or retroactive. ${ }^{18}$ It is treated as a separate and distinct presumption, despite being very similar to the presumption against retrospectivity. As will be discussed in a later section of this article, the signing of a contract is typically enough to grant the contractor a vested right. Therefore, in this example, the legislative interference with the contract would most likely grant Party B the protection of the presumption against interference with vested rights. This is the case whether the legislation has retroactive effect or retrospective effect; both would have the effect of depriving Party B of their vested right to the benefits of the contract. 
Finally, there is a presumption that where a legislative change affects a mere procedure rather than a substantive right — namely, the manner of a right's use rather than the right itself - such a change takes effect immediately. ${ }^{19}$ However, a procedural enactment, which has the effect of impeding upon the use of a substantive right, cannot be presumed to apply immediately to ongoing legal situations. The underlying principle behind this distinction appears to be that mere procedural rights, which govern the manner in which substantive rights are used, should not benefit from the same sort of temporal preservation as the substantive right itself - likely in order to guarantee procedural uniformity in the courts. As noted above, this consideration is most often seen in the context of litigation or administrative law. In Dineley, the Supreme Court grappled with a legislative change that simply altered a rule of procedure, but had the effect of fully preventing the defendant from using a particular defence to his criminal charge. Justice Deschamps, for the majority, stated that "[n]ot all provisions dealing with procedure will have retrospective effect. Procedural provisions may, in their application, affect substantive rights. If they do, they are not procedural and do not apply immediately. ${ }^{20}$ She therefore concluded that the true analysis involves finding whether or not a provision affects substantive rights, rather than simply labelling the provision "procedural" or "substantive." ${ }^{21}$ The logical corollary to this conclusion is that a vested right must be a substantive right and not a pure procedure; otherwise, the legislation takes immediate effect, and a claimant would be unable to protect the right in question. ${ }^{22}$

\section{SEPARATING VESTEd Rights From RETROSPECTIVITY}

A complicating factor involved in discussing the presumption against vested rights is that courts often conflate it with the presumption against retrospective application of statutes, without separating the two presumptions properly. ${ }^{23}$ This issue likely stems from the fact that, in the earliest English cases dealing with the two presumptions, they were largely indistinguishable. It is not difficult to see why; situations that affect the future legal effects of past events have a tendency to also affect vested rights. ${ }^{24}$ Furthermore, many of the considerations at play in determining whether to apply the presumption against retrospectivity are also the same considerations underlying the presumption against interference with vested rights. ${ }^{25}$ In the above scenario for example, the fact that the legislature is attempting to curb the negative impact of loan sharks on the public (namely, 19 One of the oldest cases on the topic offers the following example: "[i]f an act of parliament were to
provide that in matters of mere opinion no more than three witnesses shall be called, after that no person would be entitled to call more than three witnesses on such points in any pending suit, because it would be a mere regulation of practice" (Wright $v$ Hale (1860), $6 \mathrm{H} \mathrm{\&} \mathrm{N} 227$ at 230 [emphasis added]). However, Dineley, supra note 5, and much of the jurisprudence it relies on, would qualify that statement by saying that it is only a pure procedure or a mere regulation of practice so long as it does not affect a substantive right. So a person who had relied on calling more than three expert witnesses in order to make out their defence, and whose defence would be prejudicially affected by the limitation, will likely have a strong argument that the legislative change is not purely procedural, but rather affects substantive rights, and therefore does not apply immediately.

Dineley, ibid at para 11.

Ibid.

For a more expansive discussion of the distinction between "procedural" and "substantive," see ibid at paras 52-54.

Almalki, supra note 6 at para 31.

Sullivan, Construction, supra note 4 at para 25.77.

Acme, supra note 6. 
targeting a public "evil") would be a key consideration in deciding whether to rebut both presumptions.

In an effort to address this confusion, Driedger proposed that a statute cannot be considered to have retrospective effect simply because it interferes with a vested right. ${ }^{26}$ As support for this statement, he offered the following distinction between retrospectivity and interference with vested rights: whereas the vested rights presumption protects rights acquired by either past events or characteristics, the presumption against retrospectivity only attaches to past events. ${ }^{27}$ Driedger explained the distinction as follows:

\begin{abstract}
It is submitted that where the fact-situation is a status or characteristic (the being something), the enactment is not given retrospective effect when it is applied to persons or things that acquired that status or characteristic before the enactment, if they have it when the enactment comes into force; but where the factsituation is an event (the happening of or the becoming something), then the enactment would be given retrospective effect if it is applied so as to attach a new duty, penalty or disability to an event that took place before the enactment. ${ }^{28}$
\end{abstract}

The reason for this distinction is that when a legislative change addresses a particular characteristic, the moment when a person acquired that characteristic is irrelevant; the legislature is presumed to be targeting all persons who possess that characteristic. For example, legislation that provides protection for widows applies to all widows, regardless of when they became widows. ${ }^{29}$ Similarly, imagine that the 2018 legislation mentioned above were instead to read: "a person who is not employed at a licensed car dealership cannot demand or accept an interest rate above 5 percent on a car repayment loan to a borrower." Rather than dealing with a past legal event, such as the signing of a contract, this situation now targets a status or characteristic: Party B's status as a licenced car dealer. According to Driedger, such a situation would not engage the presumption against retrospective operation. ${ }^{30}$ It would, however, engage the presumption against interference with vested rights, demonstrating how the two presumptions are distinct. Party B would not benefit from the protection of the presumption against retrospectivity, but would nonetheless have the vested rights presumption operating in their favour to preserve the contractual rights. This is because Party B has a vested right to the benefits of the contract, and the new legislation - whether it targets an event or a status - interferes with that vested right.

As an additional example, if Parliament intends to pass legislation updating certain banking regulations, two possible drafting options for one of the provisions may be on the table:

(1) "No convicted fraudster may work in Canada's banking sector."

(2) “Anyone who commits a fraud is barred from working in Canada's banking sector."

26 Driedger, "Reflections," supra note 13 at 266.

Elmer A Driedger, Construction of Statutes, 2nd ed (Toronto: Butterworths, 1983) at 191-92 [Driedger, Construction].

28 Ibid at 192. This distinction was adopted by the Supreme Court of Canada in Benner $v$ Canada (Secretary of State), [1997] 1 SCR 358 at paras 42-43 [Benner].

Driedger, "Reflections," supra note 13 at 266-67, citing The Queen v St Mary, Whitechapel (1848), 116 ER 811 at 812 .

For a more thorough explanation of this distinction, see Driedger, Construction, supra note 27 at

191-97, where he reviews the extensive case law that supports his position. 
Enactment (1) displays an intention to tack a prohibition on individuals on the basis of their characteristics - the time at which they became fraudsters is irrelevant, it is the fact that they are fraudsters that is being addressed. The legislature appears to want to keep unethical people out of the profession, regardless of when they became unethical. The lack of an event in the subject of this enactment cuts off the possibility of a retrospective operation argument. Therefore, according to Driedger, the presumption against retrospective operation does not apply in such situations - a banker who has previously been convicted of fraud would have to rely on the presumption against interference with vested rights instead.

However, in the wording of enactment (2), the prohibition is being tied to an event rather than a characteristic. The distinction is subtle, but crucial. In this enactment, the question arises as to whether it is meant to affect those who have committed fraud in the past, or only those who commit fraud in the future. For example, the legislature may be choosing to add an additional penalty onto the crime of fraud as a deterrence for future offences, rather than to address the ones that have already occurred. This is an argument that would need to be made with resort to the purpose of the statute and the intention of the legislator, but the fact that the wording targets the "happening" of something means that the presumption against retrospectivity can potentially be applied.

Despite efforts by various authors and judges to keep the vested rights presumption and the presumption against retrospectivity separate, there are many instances where judges have conflated the two. In Dineley, for example, Justice Deschamps described the two presumptions as follows:

More specifically, where legislative provisions affect either vested or substantive rights, retrospectivity has been found to be undesirable. New legislation that affects substantive rights will be presumed to have only prospective effect unless it is possible to discern a clear legislative intent that it is to apply retrospectively. ${ }^{31}$

The majority of the Supreme Court in Dineley thereby tied one presumption to the other. This error was later repeated by the Ontario Court of Appeal in 1392290 Ontario Ltd. v. Ajax (Town), where the Court stated that: "[w]here vested rights are affected, the courts will find retrospective application only if this legislative intent is express or "plainly manifested by unavoidable inference." "32 Côté further complicated the matter when he stated that "a retrospective law is, substantially, a law with prospective effect which affects vested rights," and that the "presumption against retrospection converges with the presumption of noninterference with vested rights," suggesting that the two are so similar as to essentially be redundant. $^{33}$

31 Dineley, supra note 5 at para 10. This description was explicitly refuted in Almalki, supra note 6(Justice Gauthier explained that "because of the difficulty involved in temporal application in the absence of clear transitional provisions, one should keep those concepts separated to ensure that proper weight is given throughout the purposive analysis. For example, it is clear that Justice Deschamps did not mean to change the applicable rules of interpretation at paragraph 10 of Dineley" at para 31).

322010 ONCA 37,64 MPLR (4th) 170 at para 36 [Ajax]. See also para 30, where the Court suggests that interference with vested rights "attracts" the presumption against retrospectivity.

33 Côté, supra note 2 at 143-44, citing Co-operative Trust Co of Canada v Lozowhuk, [1994] 4 WWR 733 at 742 (Sask QB). 
Statements such as these contradict the precedent set by West v. Gwynne in 1910, which first created a distinction between interference with vested rights and retrospectivity, and ensured that their respective presumptions would be separated thereafter. ${ }^{34}$ Every now and again a case such as Almalki is published, which reminds readers that the presumption against interference with vested rights "generally applies to all statutes, not only those that are retroactive or retrospective." ${ }^{\prime 35}$ While the distinction between the two presumptions can at times be hair-splitting to the point of making them seemingly redundant, keeping the two presumptions separate helps the authorities on the topic become more consistent with each other. ${ }^{36}$

\section{THE BROAd ORIGINS AND NARROWING DeVelopment of The Presumption}

The presumption against interference with vested rights' origins in the common law can be traced back to the mid-1600s in Sir Edward Coke's Institutes of the Laws of England, where he stated the maxim nova constitutio futuris formam imponere debet, non praeteritis, ${ }^{37}$ meaning that "except in special cases the new law ought to be so construed so as to interfere as little as possible with vested rights." parliament" 39 was later interpreted by the Supreme Court of Canada as meaning that "when Parliament intends prejudicially to affect such rights or such a status, it declares its intention expressly, unless, at all events, that intention is plainly manifested by unavoidable inference." 40

\section{A. GILMORE V. SHUTER; MOON V. DURDEN}

Early English jurisprudence on this topic is marked by the great importance placed on preserving vested rights. The concept of interference with vested rights made an appearance in the courts in a 1677 United Kingdom King's Bench decision, Gilmore v. Shuter. ${ }^{41}$ Gilmore had been verbally promised what amounted to $2000 \mathrm{l}$ by the deceased, Shuter, to be paid either during his life or after his death, upon Gilmore's marriage to a particular woman. ${ }^{42}$ But shortly after Shuter died, the Statute of Frauds came into effect, declaring that after the 24th of June, 1677, no action shall be brought upon any promise in consideration of marriage without a writing testifying the same. ${ }^{43}$ The promise having been unwritten, Gilmore brought an action against Shuter's estate and alleged that he had a vested right to the amount promised, despite the implementation of the Statute of Frauds. The Court agreed, explaining that it was not Parliament's intent to have the Statute of Frauds apply to promises made

\footnotetext{
(1910), [1911] 2 Ch 1 (CA) at 11-12 [West]; Driedger, Construction, supra note 27 at 186-89. Almalki, supra note 6 at para 28. Gustavson Drilling (1964) Ltd v MNR(1975), [1977] 1 SCR 271 at 282 [Gustavson], says almost the exact same thing.

For a full analysis of the characteristic and event distinction in applying retrospectivity, see Benner, supra note 28 at paras $39-59$.

37 Edward Coke, The Second Part of the Institutes of the Laws of England: Containing the Exposition of Many Ancient and Other Statutes (Abingdon, UK: Professional Books, 1986) at 292.

Reid v Reid, [1886] 31 Ch D 402 (CA) at 408.

Coke, supra note 37 at 292.

Spooner Oils Ltd v Turner Valley Gas Conservation Board, [1933] SCR 629 at 638.

(1677), 83 ER 531 [Gilmore 1].

Gilmore v Shuter (1677), 84 ER 1170 at 1170 [Gilmore 2].

Statute of Frauds, 1677 (UK), 29 Cha 2, c 3, s 4, cited in Gilmore 1, supra note 41.
} 
before it came into effect. This conclusion, it declared, was "a construction agreeable to justice." 44

In Moon v. Durden, decided nearly 200 years later in 1848, the majority of the Court of Exchequer built upon the precedent set by Gilmore. ${ }^{45}$ The majority ruled that a man who had won a wager, and received a promise to be paid the result of that wager, had the right to continue his action to enforce his claim in court despite the passage of a new statute, stating:

That all Contracts or Agreements, whether by Parol or in Writing, by way of gaming or wagering, shall be null and void; and that no Suit shall be brought or maintained in any Court of Law or Equity for recovering any Sum of Money or valuable Thing alleged to be won upon any Wager. ${ }^{46}$

In holding that this statute was not applicable to the plaintiff's current action, Baron Rolfe made several strong remarks about Coke's maxim, noting its "obvious consonance with natural justice," 47 and that "the principle is one of such obvious convenience and justice, that it must always be adhered to in the construction of statutes, unless in cases where there is something on the face of the enactment putting it beyond doubt that the legislature meant it to operate retrospectively." 48 Baron Alderson, concurring, made a similar comment: "for it is contrary to the first principles of justice to punish those who have offended against no law; and surely to take away existing rights without compensation, is in the nature of punishment." ${ }^{49}$ He concluded that taking away an "existing right of action already pending" was "so gross an act of injustice" that a construction that led to that result was inappropriate. ${ }^{50}$

I list this maxim and these two cases in order to demonstrate the sweeping authority and strength that the presumption against interference with vested rights carried during its origins. As will become apparent through a perusal of the following cases however, the presumption against interference with vested rights became much more heavily qualified and easily rebuttable as time went on.

\section{B. ABBOTT V. MINISTER FOR LANDS}

Abbott v. Minister for Lands, decided in 1895 by the Judicial Committee of the Privy Council, marked a strong turn in the jurisprudence surrounding the vested rights presumption. ${ }^{51}$ Abbott, a landowner, had the right prior to 1884 to make additional, conditional purchases of land surrounding his own. This right was extinguished with the implementation of the Crown Lands Act of $1884,{ }^{52}$ but Abbott nevertheless attempted to make conditional land purchases in 1892 . When these were blocked by the Land Appeal Court, Abbott resorted to the saving proviso of the statute, which read: "[a]ll rights accrued

Gilmore 2, supra note 42 at 1171.

(1848), 154 ER 389 [Moon].

Gaming Act, 1845 (UK), 8 \& 9 Vict, c 109, s 18, cited in Moon, ibid at 390.

Moon, ibid at 396.

Ibid at 394. It bears mentioning that at this early point in the development of the presumption, there was no distinction between "retrospectivity" and "interference with vested rights."

Ibid at 397.

Ibid.

Abbott v Minister for Lands, [1895] UKPC 17, [1895] AC 425 [Abbott].

(NSW), 48 Vict No 18, s 2. 
and obligations incurred or imposed under or by virtue of any of the said repealed enactments shall subject to any express provisions of this Act in relation thereto remain unaffected by such repeal., 53

The Privy Council tentatively recognized the ability to make a conditional purchase as a right, but faced with the broad repercussions of keeping this right alive, they ruled against Abbott by not recognizing it as a vested right:

It may be ... that the power to take advantage of an enactment may without impropriety be termed a "right"... [Their Lordships] think that the mere right (assuming it to be properly so called) existing in the members of the community or any class of them to take advantage of an enactment, without any act done by an individual towards availing himself of that right, cannot properly be deemed a "right accrued" within the meaning of the enactment. ${ }^{54}$

This decision is noteworthy as it is one of the first to place strong limitations on the application of the presumption against interference with vested rights. Abbott established that, at a very minimum, some sort of action must have been taken towards claiming the generally available right in order for it to count as an "accrued" or vested right. Referring back to the framework proposed at the outset of this article, Abbott did not engage in an interpretation exercise to discern the legislative intent behind the statute, but instead ended its analysis at the second stage by finding that there was no vested right in the first place. This case is widely cited in later Canadian jurisprudence, and appears to have been the foundation for a more limited application of the vested rights presumption.

\section{WEST V. GWYNNE}

Decided in 1911, West involved a landlord who attempted to extract a fee from prospective assignees of a lease in exchange for his consent to the assignment, despite new legislation having come into effect prohibiting landlords from doing so. ${ }^{55}$ This case made two noteworthy contributions to the theory of vested rights. First, Lord Justice Buckley proposed a distinction between the concepts of retrospectivity and retroactivity, and vested (or "existing") rights: "[t]o my mind the word 'retrospective' is inappropriate, and the question is not whether the section is retrospective. Retrospective operation is one matter. Interference with existing rights is another." ${ }^{, 6}$ Up until this point, the two concepts had been merged into one presumption. The split between them has since been largely accepted by the common law, though many decisions (as noted above) have subsequently failed to separate the concepts. Second, the judicial opinions in the case suggest a certain exasperation with the concept of vested rights, as they point out how pervasive vested rights really are. Lord Justice Buckley stated that "[m]ost Acts of Parliament, in fact, do interfere with existing rights."

\footnotetext{
53 Ibid, s 2(III)(b). Note that the terms "vested right" and "accrued right" are used interchangeably throughout the jurisprudence.

Abbott, supra note 51 at 431.

West, supra note 34 at $1-2$.

Ibid at 11-12.

Ibid at 12 .
} 
Master of the Rolls Cozens-Hardy expressed the same in his reasons. ${ }^{58}$ These remarks are often cited in later jurisprudence as support for a more limited conception of vested rights. ${ }^{59}$

West also stands apart from much of the rest of the jurisprudence in that it highlights some of the negative effects of preserving vested rights. Master of the Rolls Cozens-Hardy, in deciding not to preserve vested rights, noted that doing so would "render [the law] inoperative for many years wherever leases for 99 years, or it may be for 999 years, are in existence. ${ }^{\prime 60}$ Lord Justice Kennedy, in his reasons, chose to weigh the advantages and disadvantages of exempting the leases, and found that the disadvantages incurred by some of the lessors was more than outweighed by the advantages of a "just alteration," which affected all of the existing leases. ${ }^{61}$ Both of these points highlight the consequences of unqualifiedly protecting vested rights and demonstrate a strong shift away from the presumption's past strength.

\section{The Presumption's Twentieth Century TREATMENT IN CANADA}

\section{A. ACME Village SCHOOL District No. 2296 V. STEELE-SMITH}

All of this past English jurisprudence provided much of the foundation for how Canadian courts chose to approach vested rights in the early 1900s. The presumption against interference with vested rights was most thoroughly explored first in Acme. ${ }^{62}$ Having explicitly recognized Coke's presumption several years earlier in Upper Canada College v. Smith, ${ }^{63}$ the Supreme Court in Acme then examined the rationale underlying the presumption against interference with vested rights. In this case, a new law had come into force in Alberta mandating that schools needed to receive the approval of an inspector before terminating a teacher. ${ }^{64}$ Steele-Smith was a teacher whose employment contract's formation preceded the coming into force of the new School Act, $1931 .{ }^{65}$ One month after the School Act took effect, his school attempted to terminate his employment without consulting an inspector first, arguing that the school had a vested right to terminate ongoing contracts which preceded the new legislation. ${ }^{66}$

Justice Lamont, whose reasons are cited approvingly in Dikranian v. Quebec (Attorney General) ${ }^{67}$ (discussed below), did not dwell much on whether the school had a vested right to terminate an employee without permission — he seems to have taken it as self-evident that it did, saying that it "amounted ... to something more than a mere matter of procedure" but rather looked at whether or not the presumption against interference with vested rights

Ibid at 11 .

Acme, supra note 6 at 53, 60; Smith, supra note 1 at 421-22.

West, supra note 34 at 11 .

Ibid at $16-17$.

Supra note 6.

Supra note 1 at 421.

School Act, 1931, SA 1931, c 32, s 157, cited in Acme, supra note 6 at 48.

Acme, ibid at 47.

Ibid at 48 .

2005 SCC 73, [2005] 3 SCR 530 at paras 32, 35 [Dikranian].

Acme, supra note 6 at 51. This further reinforces the idea that the procedural/substantive distinction should be utilized in determining whether a right is important enough to be considered "vested." 
should be rebutted. He noted that the presumption's foundation rested on the fact "that it would be unfair and unjust to deprive people of rights acquired by transactions perfectly valid and regular at the time they were acquired, and that the legislature is not to be presumed to act unjustly." ${ }^{\circ 9}$ This rationale would seem to operate in favour of the school board, but Justice Lamont then cited an excerpt from Craies on Statute Law, 3rd ed: "[i]f a statute is passed for the purpose of protecting the public against some evil or abuse, it will be allowed to operate retrospectively, although by such operation it will deprive some person or persons of a vested right.,"70

Justice Lamont also went on to cite West, pointing out Lord Justice Buckley's remark that "most Acts of Parliament do in fact interfere with existing rights." 71 A majority of the Court ruled in Steele-Smith's favour, declaring that the new School Act was to be immediately applied so as to protect him from arbitrary termination. ${ }^{72}$ In doing so, the majority noted that the purpose of the legislation "evidently was to prevent, except for some sufficient reason, the cancellation of teachers' contracts during the teaching days of the school year, and the disturbing and detrimental effects thereof upon the work of the schools." 73

Acme is a noteworthy case because it highlights the criteria to be considered in rebutting the vested rights presumption; in terms of the framework proposed at the outset this article, Acme shows what should be considered in the final step of a vested rights analysis. The presumption against interference with vested rights can be rebutted if it is shown that the "evil" or "abuse" that is being addressed sufficiently outweighs the need to protect the vested rights of the party affected by the statutory change. Justice Lamont looked to the language and scope of the Act in his analysis, but the fact that the legislation was remedial because it targeted a "presently existing evil" or "mischief" was the main factor that led him to firmly rebut the presumption. ${ }^{74}$ Justice Crocket, in addition to highlighting the remedial nature of the School Act, took into account the desirability of applying the law uniformly to all teachers (rather than some being effected and others not), and the fact that the legislation's delayed implementation had already served to give advance notice to school boards (thereby lessening the prejudice suffered). ${ }^{75}$

\section{B. GUSTAVSON DRILLING (1964) LTD. V. MNR}

It appears that the most widely cited case in Canadian law dealing with vested rights is the Supreme Court's 1975 decision Gustavson Drilling (1964) Ltd. v. MNR. ${ }^{76}$ The facts of the case revolved around who was to receive the tax benefits from a past transaction, following a change to the Income Tax Act. ${ }^{77}$ Company A had incurred certain tax-deductible expenses, and the structure of the subsequent sale of its property to Company B resulted in those tax

Ibid.

Ibid at 53, citing William Feilden Craies, A Treatise on Statute Law, 3rd ed by JG Pease \& JP Gorman (London, UK: Sweet \& Maxwell, 1923) at 336.

Acme, ibid.

Ibid at 52.

Ibid at 56.

Ibid at 52.

Ibid at 57-59. For another summary of this case, see Côté, supra note 2 at 181-83.

Supra note 35.

RSC 1952, c 148. 
deductions remaining with Company A so that it could choose to claim them in the future. ${ }^{78}$ Sometime after the transfer of property however, changes were made to the Income Tax Act which had the effect of transfering the benefit of those deductions from Company A to Company B. ${ }^{79}$ Company A (Gustavson Drilling) argued that the deduction should remain with it rather than Company $\mathrm{B}$, raising the presumption against retrospectivity and the presumption against interference with vested rights as support for this argument. ${ }^{80}$

Following in the footsteps of West and Abbott, Justice Dickson for the majority wrote that "[i]t is perfectly obvious that most statutes in some way or other interfere with or encroach upon antecedent rights," ${ }^{\prime 1}$ and that "[t]he mere right existing in the members of the community or any class of them at the date of the repeal of a statute ... is not a right accrued." ${ }^{82}$ Since there is no blanket right to the continuation of the law as it once stood, Gustavson Drilling could not be said to have a vested right to its tax deductions. This decision therefore made it clear that simply having resort to a statutory right is not enough to make it "vested"; more is required in order to show that the right has been sufficiently claimed.

Interestingly, the majority decision in Gustavson is difficult to reconcile with cases that state that a party's rights are crystallized at the formation of a contract. One of the principles Gustavson stands for appears to be that tax law is an exception to the rule established in these cases, given how it is constantly in flux, thus making it unreasonable to provide for vested rights in such instances. ${ }^{83}$ In Justice Pigeon's dissent, he argued that "the effect of the contract was to leave the entitlement to the deductions intact in the hands of the transferor but, if the legislative change is read as applicable to that contract, the result is an outright forfeiture or confiscation of this valuable right, the transferee having been wound-up." ${ }^{84}$ Despite this, however, the signing of a contract was not sufficient to crystallize the claimant party's rights, with the majority refusing to grant the company a vested right to its deductions. ${ }^{85}$ Indeed, later on in Épiciers Unis Métro-Richelieu Inc., division "Éconogros" v. Collin, the Supreme Court of Canada stated that, despite the signing of a contract being generally enough to create vested rights, Gustavson is an example of this principle not being absolute and being "subject to certain exceptions expressly or implicitly provided for by the legislature." 86

Gustavson, supra note 35 at 274-77.

Ibid.

Ibid at 280 .

Ibid at 282 .

Ibid at 283 .

See ibid at 282-83: "in tax law it is imperative that legislation conform to changing social needs and governmental policy." See also Ajax, supra note 32 ("[t]ax unfairness is clearly a public harm with widespread and serious consequences. This backdrop, in my view, would in any event have deprived the presumption against retrospectivity of much of its impact" at para 43).

Gustavson, supra note 35 at 288-89.

Ibid at $283-84$.

2004 SCC 59, [2004] 3 SCR 257 at para 48. 


\section{The Modern Refinement of the Presumption}

\section{A. Scott V. College of Physicians AND SURGEONS OF SASKATCHEWAN}

One of the most thorough explanations of the vested rights presumption was written by the Saskatchewan Court of Appeal in Scott v. College of Physicians and Surgeons of Saskatchewan, which provided a clear framework for deciding whether a right can be considered a vested right. ${ }^{87}$ In this case, the Court stated that " $[\mathrm{t}]$ he individual claiming the right must have placed himself in a distinctive legal position, that is, to be in a position different from other members of society." ${ }^{\prime 8}$ This criterion follows in the footsteps of Abbott and Gustavson, where the mere option to exercise a right was not enough for it to be recognized as a vested right. Furthermore, Scott adds to the analysis by clarifying that the right must be sufficiently exercised before it can be considered vested: according to Justice Vancise, "[w] hat is clear is that some step must have been taken or some event must have occurred toward the realization of the right before the repeal of the enactment." ${ }^{\text {" Justice }}$ Cameron, in his concurring opinion, went one step further and added that "the events giving rise to the right, or the conditions upon which it depends for its existence ... must have occurred or been met in advance of repeal.",90

From these criteria, it is evident that, at a minimum, an individual must take tangible steps to claim a right in order for it to count as an acquired right. The signing of a contract appears to usually be sufficient (Gustavson being one exception), but other situations can be more complicated. In the case of Scott, the plaintiff was a physician who had been dismissed from the Saskatchewan College of Physicians and Surgeons. ${ }^{91}$ He subsequently took numerous, substantial steps to get himself re-entered in the register for the College of Physicians and Surgeons, such as inquiring as to the requirements of re-registration, and completing an application to do so..$^{92}$ However, Scott took issue with the College's quantification of his penalty fees, which he intended to pay following the resolution of the issue. ${ }^{93}$ While this matter was under dispute, an amendment was made to the Medical Profession Act, 1981, ${ }^{94}$ which effectively barred Scott from reinstatement. Despite the fact that the new statute would have deprived him of the right to re-enter the College, the Court found that Scott had obtained either an accruing or accrued right to re-enter thanks to the steps he had already taken. Because the only thing that stood between Scott and reinstatement was a simple quantification of the penalty fee, the Court found that the steps taken were substantial enough to secure either an accrued or accruing right to reinstatement. ${ }^{95}$

(1992), 95 DLR (4th) 706 [Scott].

Ibid at 727.

Ibid at 728 .

Ibid at 716 .

Ibid at 708-709.

Ibid at 709 .

Ibid.

SS 1980-81, c M-10.1, s 40(2).

Scott, supra note 87 at $721,731-32$. 


\section{B. R. V. PUSKAS}

R. v. Puskas, ${ }^{96}$ a Supreme Court of Canada case decided some time later, adopted the framework that Justice Cameron proposed in Scott. In Puskas, changes were made to the Criminal Code, which eliminated an accused's right to appeal their case to the Supreme Court as of right (without being granted leave to appeal) if their acquittal had been overturned at a court of appeal and a new trial had been ordered. ${ }^{97}$ At the time these changes came into effect, the Court of Appeal had not yet rendered its decision to order a new trial in Puskas' appeal, though it eventually did do so. Ruling that the accused did not have an accrued right to appeal to the Supreme Court as of right, Chief Justice Lamer stated for the Supreme Court that:

\footnotetext{
A right can only be said to have been "acquired" when the right-holder can actually exercise it. The term "accrue" is simply a passive way of stating the same concept ... something can only be said to be "accruing" if its eventual accrual is certain, and not conditional on future events... In other words, a right cannot accrue, be acquired, or be accruing until all conditions precedent to the exercise of the right have been fulfilled. ${ }^{98}$
}

\section{DikRanian V. Quebec (ATtorney General)}

All of this culminated in the Supreme Court's 2005 decision in Dikranian v. Quebec. ${ }^{99} \mathrm{Mr}$. Dikranian was the primary plaintiff in a class action lawsuit against the Quebec government, involving approximately 70,000 students. ${ }^{100}$ Dikranian and his fellow students were the recipients of loan certificates from the provincial government, which authorized "the student to contract a loan with a financial institution."101 The government was the guarantor of the interest to be repaid on the loan, and before 1997 "exempted students who had completed their studies from paying interest on their loans" for a certain period. ${ }^{102}$ Ruling that the student borrowers had a vested right to an exemption period from paying interest on their student loans, which the amendments did not alter, Justice Bastarache adopted Côté's criteria for the recognition of vested rights, paraphrasing Justice Vancise's reasons in Scott as he did so. First, "the individual's legal (juridical) situation must be tangible and concrete rather than general and abstract"; ${ }^{103}$ Justice Vancise provided the best description of this criteria in Scott where he stated that " $[\mathrm{t}]$ he individual claiming the right must have placed himself in a distinctive legal position, that is, to be in a position different from other members of society." 104 Therefore, a right must be particular to an individual in order for it to be

\footnotetext{
[1998] 1 SCR 1207 [Puskas].

Ibid at para 1.

Ibid at para 14

Supra note 67.

Ibid at para 1 .

Ibid at para 6.

Ibid.

Ibid at para 37 [emphasis added]. I disagree with both Justice Vancise and Justice Bastarache's uses of the word "tangible," preferring either instead the word "particular" (as used by Justice Vancise in Scott, supra note 87 at 727) or "specific" (as used by Côté, supra note 2 at 170). The word "tangible" does not connote a need to distinguish between individual rights and the rights of a general population, as the words "particular" or "specific" do. 
considered vested. Second, the "legal situation must have been sufficiently constituted at the time of the new statute's commencement." ${ }^{105}$ As an example, he noted that

just as the hopes or expectations of a person's heirs become rights the instant the person dies ... and just as a tort or delict instantaneously gives rise to the right to compensation ... rights and obligations resulting from a contract are usually created at the same time as the contract itself. ${ }^{106}$

Several aspects of the Dikranian decision warrant specific mention. First, Dikranian made it clear that the signing of a contract is usually enough to crystallize a party's rights and obligations, making the right an acquired right, which attracts the presumption. ${ }^{107}$ Justice Rothman at the Quebec Court of Appeal put it most succinctly where he stated that the rights in question "were crystallized, finalized and definitively concluded under the terms and conditions of the contract." 108 Second, Justice Bastarache avoided making any strong conclusions on when a situation is "strongly constituted" enough to create a vested right, leaving it open to interpretation as to where this line falls; the following section of this article discusses this point further. Finally, Justice Bastarache's analysis focused predominantly on whether a vested right existed at all, and within this stage of the analysis no mention was made of any contextual considerations such as the unfairness of the deprivation or its prejudicial effect on either party. This reinforces the idea that context is not relevant in determining whether a right should amount to a vested right, since to do so would distort the tests that have been laid out in both Dikranian and Scott. While the unfairness and prejudice that Dikranian suffered by being denied the benefits of his student loan were factors that needed to be considered at a later stage, they were not relevant to whether or not his rights under that loan certificate placed him in a distinctive legal position, or were sufficiently constituted. A vested right is a vested right, whether or not the claimant finds himself or herself in a prejudiced or unfair position.

\section{DEFINING THE SCOPE OF A Vested RIGHT}

Having summarized the most important cases on the topic, my analysis now turns to specific outstanding issues with vested rights that need to be addressed. On several points, the latest jurisprudence surrounding vested rights appears to be in agreement: the right in question needs to be particular to an individual and it needs to be sufficiently exercised. However, some ambiguity still remains. For example, just how well constituted does a right need to be in order for that right to be "sufficiently exercised"? Does the ability to exercise that right either now or in the future need to be a certainty?

In Canada, many jurisdictions have enacted legislation on statutory interpretation, which among other functions, codifies the various presumptions that have been handed down by the common law. Many of these acts, including the federal Interpretation Act, provide not only for the preservation of "accrued" rights upon the repeal of an enactment, but also for the

Dikranian, supra note 67 at para 37 [emphasis added].

Ibid at para 40 [citations omitted].

Again, Gustavson is an exception to this rule.

Dikranian, supra note 67 at para 49, citing Dikranian c Québec (PG), 2004 CanLII 76514 at para 34 (Qc CA). 
preservation of "accruing" rights. ${ }^{109}$ This adds an extra layer of complication to the analysis. The presumption against tautology dictates that no words in a provision are used without meaning or function; ${ }^{110}$ therefore, "accruing" and "accrued" must be distinct from each other, and cannot simply be synonymous. The question then is what the threshold is for declaring that someone has an accruing right, and what the threshold is for an accrued right.

Justice Cameron in Scott proposed that for a right to be considered an accruing right, a necessary condition is the inevitability that the right will accrue to the claimant in the future:

\begin{abstract}
And so I conclude that "accruing" rights and obligations are those necessarily or inevitably, not possibly or even probably, arising in due course. In other words I am of the opinion that before a right ... may be said to be "accruing", the events giving rise to it or the conditions upon which it depends for its existence, must have been so set in train or engaged as inevitably to give rise in due course to the right and its corresponding duty. $^{111}$
\end{abstract}

It follows from this statement that the only way in which a right can be considered an accrued right is if an individual is actually capable of exercising the right at the moment when it is repealed. Given that the word "accrued" must have a higher threshold than the word "accruing," this is the only interpretation of the word, which makes sense in light of Justice Cameron's interpretation in Scott. And while Scott provided us with the threshold for an "accruing" right, Puskas built upon it and defined the scope of an "accrued" right. As mentioned above, Puskas stated that for a right to be considered "accrued," the right-holder needs to have actually been able to exercise it at the time of repeal. ${ }^{112}$ Since an accruing right requires that the right-holder inevitably be able to exercise the right in the future, it makes sense that the right-holder must be able to claim the right, without any barrier preventing him from doing so, in order for it be considered an accrued right.

If these two cases were the only authorities on the point, it would be clear that the ability to exercise the right is a necessary condition for a right to be considered "accrued"; that in order for a vested right to exist, a claimant must have been able to take advantage of the right at the time of repeal. However, Dikranian, decided seven years after Puskas, walked back slightly on this condition. Justice Bastarache, in explaining when a situation is sufficiently constituted to be considered a vested right, simply stated that " $[\mathrm{t}]$ his will vary depending on the juridical situation in question"; ${ }^{113}$ thus, it is unclear whether the actual ability to exercise the right is a requirement for it to be sufficiently constituted. It should also be noted that while the Supreme Court in Puskas cited to Justice Cameron's concurring opinion in Scott, which identified inevitability as a necessary condition for an accruing right, ${ }^{114}$ Justice Bastarache in Dikranian cited to Justice Vancise's majority opinion, which fell short of requiring an actual ability to exercise the right; Justice Vancise said only that "some step

See Interpretation Act, RSC 1985, c I-21, s 43(c): “[w]here an enactment is repealed in whole or in part, the repeal does not ... (c) affect any right, privilege, obligation or liability acquired, accrued, accruing or incurred under the enactment so repealed." See also Interpretation Act, RSA 2000, c I-8, s 35(1)(c); Interpretation Act, RSO 1990, c I-11, s 14(1)(c).

110 Sullivan, Construction, supra note 4 at para 8.23

111 Scott, supra note 87 at 719.

112 Puskas, supra note 96 at para 14

113 Dikranian, supra note 67 at para 40.

114 Puskas, supra note 96 at para 14. 
must have been taken or some event must have occurred toward the realization of the right before the repeal of the enactment."

An additional authority on the matter is the Ontario Court of Appeal's reasoning in Ajax, which interpreted the "sufficiently constituted" portion of the test in Dikranian as saying that "the appellants must demonstrate that they have exercised that right. In essence, this test demands that the rights be 'crystallized' and have 'inevitability and certainty." 116 Dikranian itself does not actually say this. Rather, the Ontario Court of Appal appears to have coloured Dikranian's criteria of "sufficiently constituted" with the previous reasoning in Puskas.

Simply stated, the question is this: should a necessary condition for an "acquired" right be the claimant's actual ability to exercise the right at the time of repeal? Furthermore, should a necessary condition for an "accruing" right be the inevitability that the right will become accrued in the future?

I would argue that Puskas and Scott should be considered the guiding authorities on this point. A right should only be an acquired or vested right if its holder can actually exercise or make use of it at the time of legislative change, and correspondingly, it should only be considered an accruing right if the ability to exercise the right will inevitably arise in the future. There are several reasons why this should be considered the law. First, a strong criticism, which can be leveled at the protection of vested rights, is that giving them a wider scope may impede upon the rule of law. One of the main principles underpinning the rule of law is that the law applies equally to all; when the law changes, uniform application of that change should generally be the preferred outcome. However, when large swaths of the population can claim exemption from this enactment by claiming it interferes with their vested rights, then this uniformity is delayed. What emerges for a time is different treatment of two groups of people, one for whom the law does not apply, and the rest for whom it does. ${ }^{117}$ Setting the bar higher by requiring that vested rights have inevitability, or that the claimant is actually able to exercise them, allows for more uniform application of the law as it reduces the size of the group that can claim protection from the change.

Second, drawing a firm line at the threshold of inevitability of a right or the actual ability to exercise that right helps to clarify the law going forward. As Côté has stated, "often little more than a guess can suggest where the judge will draw the line between vested rights and simple expectations." "118 Drawing a line in the sand, as was done in both Scott and Puskas, allows for the common law to build consistent precedent rather than relying on judicial discretion from case to case, which inevitably leads to further contradictions as the pool of case law on vested rights expands. Furthermore, placing an additional limitation on vested rights is in keeping with how the concept has evolved over time. Ever since Abbott, courts have recognized the danger of allowing vested rights to have too expansive a definition. Restricting the scope of vested rights allows them to retain some of their importance, lest they become too common, and thereby meaningless. 


\section{Defining THE STREngth OF THE Vested Rights PResumption}

The actual strength of the vested rights presumption is also a point of contention. Sullivan has classified both the presumption against retrospective application and the presumption against interference with vested rights as presumptions of "variable" strength — this classification was later adopted by the Federal Court of Appeal in Almalki. ${ }^{119}$ According to these authorities, the strength of both presumptions varies according to the "unfair or arbitrary" effect their rebuttal would create. ${ }^{120}$

Characterizing the presumption against interference with vested rights as a presumption of "variable" strength needlessly confuses the analysis. By that logic, some of the same factors, which are used to determine the strength of the presumption, would also be used to determine whether or not the presumption should be rebutted. For example, imagine that a new piece of legislation interferes with a vested right to the benefits of a contract, depriving the contractor of substantially all of its benefits. Assuming that the unfairness of this situation is severe, the strength of the presumption would probably be classified as moderately strong. That same consideration of unfairness would then, in all likelihood, be used again to help uphold the presumption against interference with vested rights. The analysis thereby becomes redundant at best, and at worst a self-fulfilling prophecy.

A better approach would be to consider the unfairness of the situation and other contextual factors only when determining whether the presumption should be rebutted, and not use them to determine the strength of the presumption at all. Once a right is deemed to be vested, the strength of the presumption should not vary from right to right on an ad hoc basis. The strength of the presumption should remain consistent across cases; otherwise, its use could become even more inconsistent than it already is. One judge may dismiss the presumption as a trivial consideration barely worthy of mention, while another upholds it as a consideration of monumental importance. As proposed at the beginning of this article, when dealing with issues of temporal application, certainty should generally be preferred over variability.

So, if the presumption's strength is not "variable," what do we classify it as? The starting point for such an exercise is to note that presumptions are only as strong as the values that underpin them. ${ }^{121}$ The presumption against interference with vested rights arose in tandem with the increasing importance courts placed on freedom from state interference with individual rights. ${ }^{122}$ Although Coke would have formulated his presumption in the early 1600 s, the principles that underlie it came to full fruition in the Glorious Revolution of 1688, when John Locke's theories on natural law began to gain influence. During this period, certain rights were held to be "beyond the reach of all governments." 123 This focus in the 1600 s on individual rights manifested itself in presumptions of parliamentary intent, such as the vested rights presumption. ${ }^{124}$ The undertones of protecting individual rights are distinctly

Sullivan, Construction, supra note 4 at para 25.25; Almalki, supra note 6 at para 34 .

Sullivan, Construction, ibid.

Ibid at para 15.13 .

JA Corry, "Administrative Law and the Interpretation of Statutes" (1936) 1 UTLJ 286 at 295.

Ibid.

Driedger, Construction, supra note 27 at 183. 
noticeable in the early cases involving the presumption; Moon, for example, treated the protection of vested rights as being conducive to natural justice. ${ }^{125}$ When the cases are read in chronological order however, it is clear that the infatuation with protecting individual rights increasingly faded away over the years. This is evident in Abbott, which reined in the scope of vested rights for fear that its accompanying presumption would be too farreaching. ${ }^{126}$ In West, the judges seemed to convey outright fatigue with the protection of vested rights, expressing doubt as to whether they deserve protection at all. ${ }^{127}$

The modern case law still recognizes vested rights as worthy of protection, but courts do not seem as zealous in defence of these rights as the courts were in the days of the Glorious Revolution. Justice Cameron in National Trust Co. v. Larsen, another vested rights decision of the Saskatchewan Court of Appeal, said that "[s]ince most statutes interfere with antecedent rights, while few operate retrospectively - one is the norm, the other the exception - the presumption against [interference] with vested rights is weaker and more readily overcome than is the presumption against retrospectivity." ${ }^{128}$ Few judges are as explicit in declaring that this is the case, but many will nonetheless hint at the weakness of the presumption in light of precedents such as Gustavson and Abbott. All in all, the vested rights presumption should be classified as a weaker presumption, though this does not mean that it is toothless; it simply takes less to rebut it than would be the case for stronger presumptions, such as the presumption against retroactivity. ${ }^{129}$

I make these recommendations for the refinement of the presumption knowing full well that the courts have on occasion only paid lip service to principles of statutory interpretation, while in reality distorting those rules in order to justify the outcome which they deem to be preferable. ${ }^{130}$ The hard distinctions above, and the clear step-by-step analysis below are intended not only to make the analysis easier to understand, but also to guard against such ideological appropriations. The benefit of having a clear structure laid out is that when a court chooses to deviate from it, it must usually voice clear reasons for why it is doing so. The same cannot be said for vague principles, whose uncertainty and broadness provide cover for judges to clothe ideological decisions in judicial language. Clarity allows us to see the reasons why a presumption shifts in strength and scope, rather than leaving us guessing as to how a judge will appropriate the presumption in order to justify a decision.

\section{Summary of the Analysis}

All of the information above can be put together into a concise framework. Imagine that a claimant is before a court, arguing that a legislative change is interfering with their vested rights, and therefore that the presumption against interference with vested rights operates so as to make a construction that interferes with those rights more difficult to justify.

See Stéphane Beaulac \& Pierre-André Côté, "Driedger's 'Modern Principle' at the Supreme Court of Canada: Interpretation, Justification, Legitimization” (2006) 40 RJT 131 at 171-72. See also Sullivan, "Ways to Cheat," supra note 10. 


\section{A. STEP ONE}

If the legislative change can be characterized as a procedural enactment, then the judge must determine if it interferes with a substantive right, or simply a rule of procedure. The majority of the Supreme Court in Dineley quoted its prior decision in Angus v. Sun Alliance Insurance Co. in order to point out the difference:

\footnotetext{
Normally, rules of procedure do not affect the content or existence of an action or defence (or right, obligation, or whatever else is the subject of the legislation), but only the manner of its enforcement or use.... Alteration of a "mode" of procedure in the conduct of a defence is a very different thing from the removal of the defence entirely. ${ }^{131}$
}

This quote highlights the idea that procedural legislation which affects the content or the existence of a substantive right cannot be considered purely procedural. On the flip side, if the judge finds that the right is purely procedural, the analysis ends there as the right in question cannot be considered a vested right.

\section{B. STEP TWO}

In order to attract the protection of the presumption, the claimant must then go on to prove that the substantive right is also an acquired or vested right. Paraphrasing Dikranian, this requires two things: that the right be particular and concrete, and that it be sufficiently constituted at the time of repeal.

Whether the first criterion is met can usually be determined with resort to the reasoning in Gustavson. If anyone in the general population can claim a certain right, an individual cannot be said to have thus gained an "acquired" right, since they have not placed themselves in a distinct position from anyone else. In essence, "the right must be acquired by a specific individual, and not the public in general" in order for it to be particular and concrete. ${ }^{132}$

Second, the claimant must prove that the right is sufficiently constituted in them; in other words, that they have taken enough steps to avail themselves of the right for it to be considered "vested." As I argued above, a necessary condition to this is that the claimant actually has the ability to exercise the right at the time the legislative change confiscates it from them. This interpretation is supported by the Supreme Court's decision in Puskas. Furthermore, in jurisdictions where Interpretation Acts provide for the protection of "accruing" rights as well as "accrued" rights, the threshold is that of inevitability; the right in question must accrue with certainty to the claimant in the future. For example, in Scott, the only thing keeping Scott from exercising his right to re-enter the College of Physicians and Surgeons was a quantification of the fee he would have to pay. Such a barrier is not sufficient to deny a claimant the existence of an accruing right. 


\section{STEP Three}

Once these requirements are met, the analysis then turns to whether the claimant's vested right attracts the presumption against interference with vested rights. Canadian courts largely resort first to the plain meaning rule of statutory interpretation, where in order for the presumption (and other rules of statutory interpretation) to operate, the legislation must be ambiguous or capable of more than one construction. ${ }^{133}$ Whether the legislation is capable of multiple interpretations is determined by considering the "entire context" of a provision." 134 If the provision is deemed to be ambiguous after this analysis, the presumption applies, and the onus then falls to the opposing party to rebut that presumption. At this point, the focus shifts from the vested right itself to the context in which it is being claimed.

Apart from the usual analysis of the language, scheme, and object of the legislation, ${ }^{135}$ a vested rights analysis also involves consideration of factors that are specific to the vested rights presumption. The factors are primarily those listed in Acme. First, one should look at the extent to which the legislation can be considered remedial: if the legislation simply shifts a benefit from one group of persons to another, then this does not connote an intention to interfere with vested rights as much as when the legislature is seeking to urgently rectify a public evil or mischief. ${ }^{136}$ Second, the flipside of this coin is to consider how arbitrary or unfair the legislative change is to the claimant: the more the claimant is unfairly impacted by the legislative change, the less likely it is that this was the legislature's intention. ${ }^{137}$

Several other factors are taken into account at this final stage as well. One of the downsides of preserving vested rights after a legislative repeal is that it essentially creates a class of persons to whom the law does not apply for a certain time. ${ }^{138}$ Thus, a judge will want to decide whether the uniform application of the law should be suspended for a time, or whether this would be so far-reaching as to render the repeal ineffective. ${ }^{139}$ Lastly, I would propose that a final consideration at this stage should be a claimant's reasonable expectations in the continuance of the right. If a person acquires a right in a highly volatile, regulatory context (namely, one where the law is subject to constant change), it can be assumed that

Driedger, Construction, supra note 27 at 184-85. Sullivan, on the other hand, is critical of the plain meaning rule, arguing that recent work in linguistics discredits the view that a text contains one "inherent meaning," which remains stable regardless of context. She therefore submits that a text can never have a fixed inherent meaning and thus be completely unambiguous, pointing to the fact that a reader's inference of the meaning of a text varies as their context does: Sullivan, "Ways to Cheat," supra note 10 at $172-74$.

134 Bell ExpressVu Limited Partnership v Rex, 2002 SCC 42, [2002] 2 SCR 559 at para 29, cited in Dikranian, supra note 67 at para 36.

135 I am referring of course to Driedger's "modern principle" of statutory interpretation, which continues to be the courts' preferred principle of interpretation today: Driedger, Construction, supra note 27 at 87. I will qualify this however by directing the reader's attention to Beaulac \& Côté, supra note 130 at 159-61, where they propose that the generality of the "modern principle" has been misused by the courts as a way to justify their interpretations after-the-fact, rather than coming to those decisions through the use of the principle itself - making it a tool for ideological justification. See e.g. Acme, supra note 6 at 52. See also Côté, supra note 2 at 169.

137 For an excellent illustration of how these two considerations compete against each other, see Moon, supra note 45 at 398 .

138 Côté, supra note 2 at 183.

See e.g. Acme, supra note 6; Larsen, supra note 128 at 279-80. See also West, supra note 34 at 11 , where Master of the Rolls Justice Cozens-Hardy points out the detrimental effects of exempting 99-year leases from the new legislation. 
they had at least somewhat of an idea that the law might one day change and deprive them of their right. ${ }^{140}$ This consideration was used to rebut the presumption in Larsen:

\footnotetext{
The change might have caught some mortgagees by surprise; and had they anticipated it they might not have been made their loans, though I hasten to add too much can be made of this in light ... of the state of the law generally in these respects. Saskatchewan lenders have long been accustomed to living with debtor legislation and limitations of this and other sorts.... I mean only to say that the legislature might more readily be taken to have intended the amendment to operate indiscriminately in the presence of these considerations than in their absence. ${ }^{141}$
}

This is not intended to be an exhaustive list, as there will most likely be other factors involved in the analysis depending on the case at hand. However, these are the considerations that appear to be the most important in a vested rights analysis. After carefully examining each of these points, a judge can then make a decision on whether the presumption against interference with vested rights is to be upheld, or rebutted.

\section{Conclusion}

The law of temporal application in Canada has been described as existing "in a state of confusion." 142 Given its over-abundance of ancient rules, fine distinctions, and inconsistent judgments, such a description is quite appropriate. While there is an argument to be made that a more abstract, principle-based approach to temporal application would make it more understandable and accessible, I suggest that what we need in this area is not fewer rules; we just need clearer ones. Through the foregoing analysis, my intent has been to clarify one aspect of temporal application in particular, that being the presumption against interference with vested rights. In doing so, I hope that I have saved some poor lawyer or law student from at least some of the headache of trying to make sense of the presumption and its jurisprudence on their own. 
[this page is intentionally blank] 